\title{
A Study on the Governance Structure of Modern Universities
}

\author{
Ma Xiaojun ${ }^{\mathrm{a}}$, Zhang Ze, Yan Ruihua, Pan Hongwei \\ College of Mechanical Engineering \\ Jiamusi University \\ Heilongjiang Province, China, 154007 \\ a mjzx2009phd@163.com
}

\author{
Li Chunjiang* \\ Dean's office \\ Jiamusi University \\ Heilongjiang Province, China, 154007 \\ jmslcj@sohu.com
}

\begin{abstract}
The university is an important position in the dissemination of culture and knowledge, and is responsible for the mission of cultivating builders and successors for the cause of socialism. Perfecting university governance structure and modern university system is the inevitable requirement of guaranteeing the quality of personnel training in colleges and universities. At present, China's universities have many problems in university system and governance structure to be solved in the process of development and reform of higher education. How to establish the rule system of management and operation which is suitable for the development of university is the core of the university system construction. The core of university governance structure is a series of institutional arrangements to coordinate the related interests. This paper focuses on the core connotation of modern university governance structure, studies the theoretical basis of university governance structure and its decision-making mechanism, and gives the research goal, reform content and model of university governance structure which is based on modern university system. Comprehensively deepen the reform of higher education, and actively explore the pattern of university governance structure, provide necessary reference for the construction of modern university governance structure and system with Chinese characteristics.
\end{abstract}

Keywords-university system; university governance; governance structure; decision-making mechanism

The rise and development of modern university governance theory is accompanied by the establishment of modern university system. Since the 20th century, with the diversification of university's function and rapid expansion of the scale of higher education, the time and space of university system have changed significantly. The traditional concept of university autonomy and academic freedom has been challenged, and the management problem of the university has become more complex. Especially the start of the popularization of higher education triggers the contradiction between university system and social transformation. In this case, western countries have continuously initiated higher education system reform. At the same time, western countries have set off a wave of governance change in the field of higher education.

In short, the so-called university governance is university's internal and external stakeholders participating in the structure and process of major university decision-making. The

Financed by Heilongjiang Higher Education Society Project: (16G206) and Heilongjiang Institutions of Higher Learning Teaching Reform Project: (JG2014011046) together

*Correspondence Author: Li Chunjiang(1970-),Professor, master tutor governance structure of the university is the essence and core of modern university system. The university governance is the institutional arrangement that links the formal and informal relations between university's internal and external stakeholders, so that the interested parties can realize the checks and balances on rights, responsibilities and interests, achieving a reasonable unity of university's internal and external efficiency and fairness. Governance involves the vertical and horizontal relations of schools, definitions of various powers, obligations and responsibilities, and patterns of various interest relationships. Governance is actually a new management model that covers all formal institutions and rules, as well as informal institutional arrangements. Compared with the previous management model, governance is more focused on coordination, rather than control. It advocates government organizations and non-governmental organizations to participate in the management of public affairs. From control to coordination and replacing management with governance has already become the trend of higher education reform in the world.

\section{THE CORE OF UNIVERSITY GOVERNANCE STRUCTURE}

The governance structure of the university refers to a series of institutional arrangements for the university to coordinate the relevant interests. The core of the university governance structure is a series of institutional arrangements to coordinate the various interests within the university. The purpose of the university governance structure is to focus on the common mission and goal of the university stakeholders, and seek common ground while reserving differences to form the coupling effect. The university governance structure is the most prominent problem faced by the reform of university leadership system, especially that how to realize the leadership of the party to the university has become the key to perfect the university governance structure. The governance structure of the university is composed of two parts: external governance and internal governance. How does external governance realize the coupling relationship between university and government and society; internal governance is the coupling relationship between university internal management and institutional system. China's universities represent the will of the state, external governance requires the top-level design at the national level, and the essence of internal governance is the institutional arrangement of university decision-making power. The internal governance of the university is that various 
interests coordinate with each other to realize the coupling relationship between university's collective leadership and its principal, administrative rights and academic rights, academic organizations, and school and students on the basis of ensuring the core of various interests.

The internal governance structure of the university mainly refers to the combination of various management powers within the university. Generally speaking, it includes academic and administrative power. Administrative power is the legal power. It takes efficiency as the goal of action, and a strict hierarchical system as the basis. Its main body is the head of university management departments and their supporting staff. Academic power is determined by the academic status of the power subject, belonging to natural power. Its main body is university professor. "The university is a fairly complex organization and a highly decentralized organization. In order to avoid the anarchy within university, which is such a highly personalized organization, strengthening scientific management is the only option".

Judging from the social attributes of the university, as a social organization, university has the basic characteristics of all social organizations. If the university wants to survive in this society, it must acquire the basic information that is sufficient to maintain its own survival. The way to obtain this information is to produce products that meet the needs of society through the university's own academic activities and then maintain its own survival and development by output and exchange. The university own academic potential and the increasingly rich society needs are at the two poles of university function, forming a unity of opposites. The exchange between university and society is the bridge for them to form connection with each other.

\section{THE THEORETICAL BASIS OF THE STUDY OF UNIVERSITY GOVERNANCE STRUCTURE AND ITS DECISION- MAKING MECHANISM}

China's study on related issues of the "university governance structure" and "university internal decision-making mechanism" under modern university system began in the late 1990s. In recent years, with the accession to the WTO and the government's call to build world-class universities call, such researches have gradually increased. Although most of these studies belong to the macro exploration and the system has not yet formed, there still are few direct researches and structure constructions about the internal governance of university. Similar results still have a good reference for this study.

The theory of higher education management has been relatively mature. The theories of modern administration, enterprise organization and management theory, organizational design theory and organizational reform and development are quite mature, which can be used as reference for this study: corporate governance theory, stakeholder theory, principalagent theory, incentive theory, consumer behavior theory and the theory of educational cost sharing have provided sufficient theoretical preparation for this study. The macro-research on higher education reform and the local strategy research of the internal management mechanism of university have accumulated some theoretical accumulation.
The reform of the university governance model and decision-making mechanism caused by the construction of world-class universities has been emerging in the near future, which involves power system, reform of personnel system within school, and discipline setting. It provides a lot of reference for this study.

In foreign countries, especially in western countries, because the university has a long history of development, the basic idea of autonomy and academic freedom in the university system has been regarded as a matter of course, that is, the core problem of the university system has been solved. Under such context, the university system research is mainly conducted in two areas. First, carry out research around the university's own educational philosophy. In such studies, the university system is considered to be the problem of the school itself, and it is the development and manifestation of different ideas under the basic framework of autonomy and freedom. The focus of study and discussion is at the university level. There is little discussion of the university system, but only when it comes to specific issues. Second, carry out research around the national higher education system and policy. It takes the university autonomy, academic freedom and related system problem as a given fact and basis, and discusses how to coordinate national policy with it.

Before 1970s, foreign research on the university system is neither systematic nor the focus of the study. Since the 1970s, due to the arrival of the era of knowledge economy, the role and status of the university has undergone great changes, and the requirement to establish a flexible and adaptive system for universities has been put on an important agenda. With the diversification of university's function and rapid expansion of its scale, traditional concept of university autonomy and academic freedom has been challenged, and the corresponding old university system has also encountered difficulties. The university's own management problems have become very complex and diverse. It has become the general concern of the higher education that how to optimize the existing internal governance structure and decision-making system of university, reform the irrational factors in the existing internal management of university, and make the university a highly effective academic institution. Around the establishment of a more effective internal governance structure and effective promotion of the healthy development of university and rapid and steady progress of social and economic construction, western countries have launched a series of research. Currently, US, UK, Europe and other countries have combined their models to learn from each other's strengths. From the literature, because this kind of research is targeted and lack of systematicness and integrity, many problems are still in the stage of development. It still has some defects on the practical application level.

China's research on the university system is basically starting from the blank. It starts slowly along with the rise of China's higher education. At the first half of the 20th century, China's university system research focused on how to follow the western advanced model, and build our own university. China's scholars have studied and compared the university system of European and American countries as well as Japan, and summed up some certain experience and achieved in-depth 
results on some issues. However, because China's higher education is still in its infancy and has not experienced more time trial, its thinking space is limited, and a lot of understandings still stay at the individual level, not rising to the systematic and rational level. The new environment coming with the reform and opening up has again brought up the question of university system.

The related articles have been published one after another, such as Yuan Guiren's "Establishment of Modern University System to Promote Higher Education Reform", Zhang Yingqiang's "Institutional Innovation and China's Construction of World-Class University" and so on. "Modern University Education" magazine also published several articles of Pan Yuyuan and others in the form of writing conversation, analyzing and discussing the establishment of modern university system in China especially. In 2004, the "China Higher Education"'s principal forum subject discussed the principal responsibility system under the leadership of party committee. People have a considerable understanding of the significance of establishing modern university systems and improving the structure of university governance. But since these studies are restarted many years later, they are lack of continuity in research. They have done a lot of repetitive work, and still stay at the stage of raising questions, forming ideas, defining concepts and elucidating the significance and value of research. The systematic research results have not yet been achieved.

\section{UNIVERSITY GOVERNANCE STRUCTURE BASED ON MODERN UNIVERSITY SYSTEM}

\section{A. Research Target}

China's university governance structure takes the Party's education its main line, and establishes modern university system and explore China's university governance structure. The university governance structure is based on the modern university system. The principal responsibility system under the leadership of Party committee is the basic system of socialism higher education with Chinese characteristics, and also the basic characteristics of China's socialist university management system. Adhering to the leadership of the Party and implementing principal responsibility system under the leadership of Party committee is the premise and political direction that we must adhere to improve the internal governance structure of university. Adhere to managing the university by law, improve the university's charter, and establish modern university system and build scientific and democratic security mechanism of university governance structure. To speed up the construction of modern university system with Chinese characteristics, first is to streamline administration and delegate power to the lower levels, expand the autonomy of colleges and universities; second is top-level design, improving the internal governance structure; third is to be prior to carry and try, continue to explore and accumulate experience.

The goal and direction of university governance structure is the embodiment and realization of modern university development goals and functions. It is the starting point and foothold of all the work of university to cultivate students. It is the basic task of university at any time. While teaching, research, social service and leading the society are the basic function of modern university. University's basic task is the central coordinate of university's function, while university's function is the necessary way to achieve the basic task of university. The improvement of university governance structure must develop around the basic problem of "what students we need to cultivate and how to do that". It must help to promote education and teaching reform and inspire the enthusiasm and creativity of teachers, and be conducive to the comprehensive development and quality improvement of the students and chiastopic fusion of disciplines. It needs to help create a good academic atmosphere and form excellent study style, school style and work style ${ }^{[8,9]}$.

\section{B. Contents of Reform}

Comprehensively promote the construction of university's charter: clarify the rights and obligations between school and government and the internal governance structure and organization operation system through the charter, and steadily push forward school's "de-administration" reform; explore the new mechanism of governance in colleges and universities: explore and establish the school committee (board of directors) system which involves the participation of organizer representatives, school's party and government leaders, faculty representatives, business representatives and social celebrities, and improve social support and long-term mechanism that supervising school's development; establish academic management system which takes academic board as its core: improve the academic management of secondary colleges, play the leading role of experts and professors on discipline construction, teaching, research and other academic affairs. At the same time, explore the effective way of professor's academic governance, and promote the relative separation of "academic power" and "administrative power"; explore the comprehensive reform which takes innovative talent cultivation as its core and secondary colleges as basic units: improve the decision-making management of department leaders and nongovernmental management of teacher's representative committee, and give departments the initiative on recruitment and selection of students, personnel training, teacher appointment and assessment, and use of funds to stimulate the vitality of departments.

\section{Structure Mode}

With the deepening of higher education reform, the university has undergone 30 years' development process of reform and opening up. According to the "Education Planning Outline", China has established 48 modern university system construction pilot projects. It issued the "Interim Measures for the Development of Charters of Universities and Colleges" and other systems, held mid-term summing-up meeting and seminar of "Building Modern University System with Chinese Characteristics" pilot work, released "Manage the University by law--Implementation Outline of Building Modern University System with Chinese Characteristics (draft)" and conducted a series of research work. Fully demonstrate the feasibility of modern university system and university governance structure. According to the level of higher education, educational concept and quality of personnel 
training in China, we need to fully refer to foreign modern university system and university governance structure, but do not just copy them, strict adhering to the Chinese characteristics. Establish systems that implement the Party's education policy and contribute to academic innovation and students' healthy growth, and improve China's university governance structure.

The construction of China's university governance structure system shoulders heavy responsibilities, colleges and universities shoulder an important historical mission. To establish the modern university governance structure system with Chinese characteristics, we must fully follow the law of higher education in China; run the school according to law and under the framework of modern university system. First is to adhere to the leadership position of Party committee in the university governance; second is to build the responsibility and power relation system of university Party committee and different administrative levels; third is to establish and improve the university charter, academic committee charter, and build system that adapts to modern university governance structure. Define the authority-responsibility relationship of the administrative body, the responsibility-power boundary and operational procedures and methods of academic committee and other academic organizations, and develop the actual decision-making power system on academic affairs for academic committee which takes professors as its main body.

Through the systematic analysis of the development process and main features of modern university system at home and abroad, university systems have differences, but their basic idea and value connotation are highly consistent. Foreign universities achieve university autonomy and academic freedom, and highlight the academic standards through professors' academic management. All their rules and regulations are tailored around academic activities. Be democratic and open, enhance the coupling relationship between external structure of university governance structure and government, society and university, and maintain the spiritual independence and self-management of university.

\section{CONCLUSION}

The construction of university system in China should fully learn from the successful experience of foreign modern university system construction, and then combine with the present situation of higher education development in China, actively explore the modern university system with Chinese characteristics. This has become an important foundation for perfecting the university governance structure. We need to improve modern university system with Chinese characteristics at following six aspects: first is to actively and steadily implement and expand the autonomy of university education; second is to managing the university by law, and promote the construction of university charter; third is to improve the leadership system of university, focusing on the improvement of principal responsibility system under the leadership of Party committee; fourth is to define the boundary of administrative power and academic power in the form of system, and reasonably divide their function; fifth is to strengthen the democratic management, improve the system of teachers' representative conference and student congress, give full play to the initiative of faculty members; sixth is to build a new relationship between university and society, let university's technical logic closely connect with market logic to serve society through the effective allocation and competition mechanism of market resources.

\section{REFERENCES}

[1] MA Xiao-jun. Experience and Enlightenment of the Governance Structure of German Universities[A]. Chongqing Technology and Business University. Proceedings of the 1st International Seminar on Education, Innovation and Economic Management (SEIEM 2016)[C].2016:5.

[2] Yao Yuhua. The Attempting Discussion of the Construction of University Governance Structure: Based on Multi-Scale Study [J]. University (Research Edition), 2016, (10): 11-19+10.

[3] MA Xiaojun, Song Yuanhang, Pan Hongwei, Xu Hongmei, Li Chunjiang. Study on University Governance Structure Based on Modern University System[J]. China Management Information, 2016, (03): 248250 .

[4] Li Liguo. University governance transformation and modernization [J]. University Education Science, 2016, (01): 24-40 +124.

[5] Ma Xiaojun, Li Chunjiang. Study on University Governance Structure Based on Modern University System [J]. Economist, 2015, (12): 236237.

[6] Chen Xiaojun. Perfect the Basic Problems of University Governance Structure in China[J]. Higher Education Review, 2015, (01): 24-31.

[7] Huang Xiaomei. Construction of University Power Supervision System in the Modern University Governance Structure[J]. Journal of National Academy of Education Administration, 2015, (06): 9-12.

[8] Ma Xiaojun, Song Yuanhang, Pan Hongwei, Xu Hongmei, Li Chunjiang Experience and Enlightenment of Foreign University Governance Structure $[\mathrm{J}]$.

[9] Li Xuyan. Comprehensive Improvement of University Governance Structure[J]. Education and Occupation, 2015, (04): 45.

[10] Ding Xiaomei. Study on University Governance Structure [D]. East China Normal University, 2014 